\title{
Anti-quorum sensing activity of phenolic extract from Eugenia brasiliensis (Brazilian cherry)
}

\author{
Adeline Conceição RODRIGUES ${ }^{1}$, Brígida D’Ávila de OLIVEIRA ${ }^{1}$, Elis Regina da SILVA ${ }^{1}$, \\ Nayara Thais Barbosa SACRAMENTO' ${ }^{1}$, Michele Corrêa BERTOLDI ${ }^{2}$, Uelinton Manoel PINTO ${ }^{3 *}$
}

\begin{abstract}
The aim of this study was to assess the anti-quorum sensing activity of phenolic extracts from grumixama (Eugenia brasiliensis), also known as Brazilian cherry, in concentrations that did not interfere with bacterial growth. The pulp phenolic compounds were extracted by using solid phage extraction in a mini-collumn C18 and quantified by spectrophotometry. The anti-quorum sensing activity was evaluated by testing the inhibition of violacein production in Chromobacterium violaceum and by evaluating the swarming motility in Aeromonas hydrophila and Serratia marcescens, both phenotypes regulated by quorum sensing. The phenolic extract strongly inhibited the production of violacein in C. violaceum, reducing its production in comparison with a control with no extract. No inhibition of growth was observed at the concentrations tested for quorum sensing inhibition. Confirming the quorum sensing inhibition phenotype, the extract was also able to inhibit swarming motility in $S$. marcescens and in A. hydrophila, although in the later the effect was marginal. Overall, these results indicate that phenolic extract from E. brasiliensis presents quorum sensing inhibitory activity most likely due to the presence of fruit phenolics which have been implicated as quorum sensing inhibitors in Gram negative bacteria.
\end{abstract}

Keywords: quorum sensing; anti-quorum sensing; phenolic extract; Brazilian cherry; Eugenia brasiliensis.

Practical Application: The phenolic extract in this study presents potential applications in the food and pharmaceutical industries due to inhibition of phenotypes regulated by quorum sensing, which include production of virulence factors and spoilage enzymes. By inhibiting phenotypes associated with quorum sensing, the extract presents potential application as a natural preservative for food conservation and as an alternative or an adjuvant with antibiotics.

\section{Introduction}

Bacteria coordinate gene expression as a function of cell density in a communication mechanism named quorum sensing (Fuqua et al., 1994). This process occurs through the production, release and detection of signaling molecules by bacterial cells (González \& Keshava, 2006). The signaling molecules are usually termed as autoinducers belonging to the acyl homoserine lactone (AHL) group, commonly referred to as autoinducer 1 (AI-1), which are used by Gram-negative bacteria; autoinducer peptides (AIP) used by Gram-positive bacteria; and autoinducer 2 type molecules (AI-2) used by both groups. Other types of signaling molecules such as p-coumaryl-homoserine lactone, unsaturated fatty acids, quinolone, and a substituted alkane, among others have also been described (Tsai \& Winans, 2010).

Through the quorum sensing system bacteria are capable of performing tasks as a group such as migration to more favorable environments, biofilm formation, virulence gene expression, bacteriocin and antibiotic production, bioluminescence, pigment production, among others (Martins et al., 2014; Skandamis \& Nychas, 2012). The system has also been shown to regulate bacterial behaviors in food ecosystems highlighting the importance of understanding its control in order to improve food safety and quality (Bai \& Rai, 2011; Pinto et al., 2007; Skandamis \& Nychas, 2012).

A disruption in any of the steps required for the quorum sensing communication could interfere with microbial pathogenesis and aid in bacterial control (González \& Keshava, 2006; Hentzer \& Givskov, 2003). This approach is part of a broader group of antivirulence strategies (Rasko \& Sperandio, 2010). Therefore, quorum sensing inhibition can be accomplished by interfering with the synthesis, secretion and degradation of the autoinducers, as well as by hampering their recognition by receptor proteins such as the LuxR type homologs, which recognize AHLs. The idea of using quorum sensing inhibitors arises from the fact that they target virulence factors with minimal to no effect on bacterial growth which could potentially decrease the risk of selecting for bacterial resistant strains (Dong et al., 2001; Hentzer et al., 2003).

Some natural compounds inhibit quorum sensing and it has been argued that this effect could have great implications in 
antivirulence strategies (Adonizio et al., 2008). The combination of these inhibitors with other traditional antimicrobials could generate synergistic effects promoting more effective control against bacterial infections in plants, animals and humans (Givskov, 2012).

Some studies have shown that plant phenolic compounds can interfere with bacterial quorum sensing (Borges et al., 2014; Issac Abraham et al., 2011). Phenolic compounds are secondary metabolites found in plants and plant derived foods such as fruits, teas and red wine (Haminiuk et al., 2012). They are used by the plants against phytopathogens, radiation and are involved in antioxidant events (Tiveron et al., 2012). Phenolic compounds are associated with stress response in plants and have recognized antimicrobial properties (Martins et al., 2015).

Eugenia brasiliensis, popularly known as grumixama or Brazilian cherry, is a fruit from the Myrtaceae family, and it has been shown to be a source of phenolic compounds (Moreno et al., 2007). The essential oil extracted from its leaves presented anti-diarrhea, anti-fever, anti-infllamatory, and antibacterial activities (Magina et al., 2009). Little is known about the antimicrobial effects of the fruit and no study has been found reporting its anti-quorum sensing activity. Therefore, this work aimed at evaluating the quorum sensing inhibitory potential of phenolic extracts obtained from E. brasiliensis fruit against commonly phenotypes regulated by quorum sensing in Chromobacterium violaceum, Aeromonas hydrophila and Serratia marcescens (Morohoshi et al., 2007; Pinto et al., 2007; Ponce-Rossi et al., 2016).

\section{Materials and methods}

\subsection{Extract preparation}

Fruits of E. brasiliensis were collected in the county of Ouro Preto - MG. The fruits were washed and sanitized with sodium hypochloride at $50 \mathrm{mg} \mathrm{L}^{-1}$ for $15 \mathrm{~min}$. The seeds were manually removed and the pulp was homogenized and kept frozen at $-20^{\circ} \mathrm{C}$ until use. Phenolic compounds were extracted as previously described (Bertoldi, 2009). Briefly, the fruit pulp was thawed and mixed with ethanol:methanol:acetone 1:1:1 (v/v/v), followed by filtration in Whatman paper $n^{\circ} 1$. Then, the resulting extract was evaporated in rotary evaporator at $40^{\circ} \mathrm{C}$ (Büchi, Switzerland) and the remaining aqueous extract applied to a mini-column

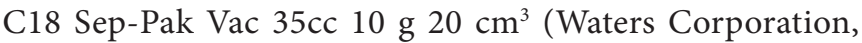
Milford, MA) for concentration and purification of phenolic compounds. The adsorbed phenolic compounds were eluted from the column with methanol, while the aqueous fraction was discarded. Then, methanol was completely evaporated in rotary evaporator at $40{ }^{\circ} \mathrm{C}$ and distilled water was added with the resulting product named phenolic extract. The term phenolic extract used frequently within this report has no relation to the solvent system used to obtain the extract. Phenol was not used as an extraction solvent and instead the term phenolic extract is used to describe an extract enriched in phenolic compounds. The total phenolic content of the extracts was determined by the Folin-Ciocalteu assay (Shahidi \& Naczk, 1996) and expressed as $\mathrm{mg}$ of galic acid equivalent per $\mathrm{L}\left(\mathrm{mg} \mathrm{GAE} \mathrm{L}^{-1}\right)$.

\subsection{Anti-quorum sensing assays}

Bacterial strains and culture conditions

C. violaceum ATCC6357 was cultured at 28 and $30{ }^{\circ} \mathrm{C}$, A. hydrophila IOC/FDA110-36 at $37^{\circ} \mathrm{C}$ and S. marcescens at $30^{\circ} \mathrm{C}$ in Luria Bertani (LB) broth containing peptone $1 \%$, yeast extract $0.5 \%$ and $\mathrm{NaCl} 0.5 \%$ (instead of 1.0\%) (Ravn et al., 2001).

\section{Agar diffusion assay with C. violaceum ATCC6357}

The assay was performed according to Tan et al. (2012), with modifications. Aliquots of $1 \mathrm{~mL}$ were mixed to $20 \mathrm{~mL}$ of fused LB agar (1.2\%) in sterile Petri plates. The plates were kept for $30 \mathrm{~min}$ after which wells of $5 \mathrm{~mm}$ were made with the use of sterile tips. To each well, $20 \mu \mathrm{L}$ of each concentration of extract (2998.5 mg GAE L ${ }^{-1}, 599.7 \mathrm{mg} \mathrm{GAE} \mathrm{L}^{-1}, 299.85 \mathrm{mg} \mathrm{GAE} \mathrm{L}^{-1}$, $199.9 \mathrm{mg} \mathrm{GAE} \mathrm{L}^{-1}$ and $149.92 \mathrm{mg} \mathrm{GAE} \mathrm{L}^{-1}$ ) were added. Plates were incubated at $28{ }^{\circ} \mathrm{C}$ for $24 \mathrm{~h}$. Sterile distilled water and kanamycin $\left(100 \mu \mathrm{g} \mathrm{ml}^{-1}\right.$ - Sigma Aldrich) were used as controls. The quorum sensing inhibitory activity in C. violaceum was verified by the formation of a turbid halo, indicated by bacterial growth, with no pigment production around the well, on a purple background on the plate.

\section{Minimum inhibitory concentration (MIC)}

The assay was performed as previously described by Wiegand et al. (2008). A population of $10^{4}$ colony forming units (CFU) of each microorganism was point inoculated in Mueller-Hinton agar (beef extract $30 \mathrm{~g} \mathrm{~L}^{-1}$, hydrolysate of casein $17.5 \mathrm{~g} \mathrm{~L}^{-1}$, starch $1.5 \mathrm{~g} \mathrm{~L}^{-1}$, agar $15 \mathrm{~g} \mathrm{~L}^{-1}$ ) added of different concentrations of the phenolic extract of Brazilian cherry. The agar assay was chosen due to the color of the extracts which would interfere in the readings in a liquid assay. Plates were inoculated for $24 \mathrm{~h}$, at optimal temperature of growth of each microorganism and MIC was determined as the lowest concentration in which no bacterial growth was observed.

All quorum sensing assays were performed in sub-MIC concentrations with no measurable interference on the bacterial growth, as determined by plating appropriate dilutions on LB agar plates and determining the population of each treatment, compared to the control in colony forming units per $\mathrm{mL}$ $\left(\mathrm{CFU} \mathrm{mL} \mathrm{mL}^{-1}\right)$.

\section{Quantification of violacein production in C. violaceum ATCC6357}

The assay was performed as described by Tan et al. (2012), with modifications. Briefly, C. violaceum was grown overnight at $28^{\circ} \mathrm{C}$ and inoculated to a final optical density of 0.1 at $600 \mathrm{~nm}$ (approximately $10^{8} \mathrm{CFU} \mathrm{mL} \mathrm{m}^{-1}$ ) in tubes containing $\mathrm{LB}$ or $\mathrm{LB}$ with phenolic extract at different concentrations. Tubes were incubated at $28{ }^{\circ} \mathrm{C}$ for $24 \mathrm{~h}$ with agitation at 150 rotations per $\min (\mathrm{RPM})$. The quantification of violacein was performed with $1 \mathrm{~mL}$ of culture from each treatment. The aliquot was centrifuged at $13 \mathrm{RPM}$ for $10 \mathrm{~min}$ in order to precipitate the insoluble violacein piment. Then, the supernatant was discarded and the pellet solubilized in $1 \mathrm{~mL}$ of dimethylsulfoxide (DMSO) with vigorous agitation, followed by another centrifugation step in 
order to remove cellular debris. The absorbance was measured in a spectrophotomer EPOCH (Bio Pek ${ }^{\bullet}$ ) set at $585 \mathrm{~nm}$. The negative control consisted of LB without the addition of the extracts (set to $100 \%$ of violacein production), while the positive control for quorum sensing inhibition consisted of the quorum chenching furanone ((Z-)-4-Bromo-5(bromomethylene-2(5H)-furanone) at a concentration of $50 \mu \mathrm{M}$ (Manefield et al., 1999). Colony forming units per $\mathrm{mL}\left(\mathrm{CFU} \mathrm{mL} \mathrm{m}^{-1}\right)$ was also evaluated after the incubation period of C. violaceum in the treatments and control in order to evaluate any growth inhibition effects.

The percentage inhibition of violacein production was calculated by using the following Equation 1:

\%inhibition of violacein production $=\left(\frac{(a-b)}{a}\right) \times 100$

Where "a" is the OD of control at $585 \mathrm{~nm}$ e "b" the OD of treatment at $585 \mathrm{~nm}$.

\section{Swarming motility assay}

The swarming motility assay was performed as described by Huber et al. (2001) with A. hydrophila and S. marcescens. Briefly LB agar was prepared to a final concentration of $0.4 \%$ of agar with the addition of the tested extract and plates were kept half open for $10 \mathrm{~min}$ in a laminar flow hood. Aliquots of $2 \mu \mathrm{L}$ of each bacterium previously grown overnight were inoculated as a spot in the center of the medium. The plates were incubated in the optimal temperature of each bacterium for $24 \mathrm{~h}$ after which the swarming motility was visually observed. The negative control consisted of LB agar without extract.

\subsection{Statistical analysis}

Data obtained for the variable (extract concentration) were compared to the negative control (no extract) in each experiment. Assays were performed in triplicate and the results expressed as average of the values of each treatment with standard deviation. The significance $(p<0.05)$ was obtained by the ANOVA test and Tukey test by using the GraphPad Prism version 5.00 software for Windows (San Diego, California, USA).

\section{Results}

The total phenolic content of the extract, as determined by the Folin-Ciocalteu assay, was $2998.5 \mathrm{mg} \mathrm{GAE} \mathrm{L}^{-1}$. The phenolic content of the extract was used as a parameter of comparison in our assays; therefore, all experiments are expressed as $\mathrm{mg} \mathrm{GAE} \mathrm{L}^{-1}$ with the intent of making future comparisons with other food matrices, also rich in phenolic compounds, more feasible.

\subsection{Agar diffusion assay with C. violaceum}

In this preliminary assay, the E. brasiliensis phenolic extract presented a potential to inhibit quorum sensing in C. violaceum, as observed on Figure 1. The result shows a clear, but turbid zone (indicative of bacterial growth) around the wells (Figure $1 \mathrm{c}$ and d), on a purple background, as opposed to a clear and transparent halo with the kanamycin control (Figure $1 \mathrm{~b}$ ), indicative of growth inhibition.

\subsection{Minimum inhibitory concentration (MIC)}

The MIC values of the phenolic extract from $E$. brasiliensis were $499.75 \mathrm{mg} \mathrm{GAE} \mathrm{L}^{-1}$ for A. hydrophila IOC/FDA110-36, $214.18 \mathrm{mg} \mathrm{GAE} \mathrm{L}^{-1}$ for $C$. violaceum ATCC6357 and higher than 149.93 GAE L $\mathrm{G}^{-1}$ for $S$. marcescens, since at this concentration there was no growth inhibition for this bacterium (higher concentrations were not tested for this microorganism). The determination of the MIC was performed in order to provide information on the concentrations used in the quorum sensing inhibition assays which were all lower than the MIC values.

\subsection{Quantification of violacein production in C. violaceum ATCC6357}

The E. brasiliensis phenolic extract, in all the tested concentrations, presented significant inhibition $(\mathrm{p}<0.05)$ of violacein production in C. violaceum, as compared to the control (Figure 2). For instance, in the concentration of $119.94 \mathrm{mg} \mathrm{GAE} \mathrm{L}^{-1}$ the extract was a better inhibitor than the positive control used in the assay ( $90 \%$ for the extract against $79 \%$ for furanone). In other lower concentrations there was still significant inhibition of violacein production as compared to the negative control. The $\mathrm{CFU} \mathrm{ml}{ }^{-1}$ counts after $24 \mathrm{~h}$ incubation in the presence of phenolic extracts did not differ statistically from the control (Figure 2).
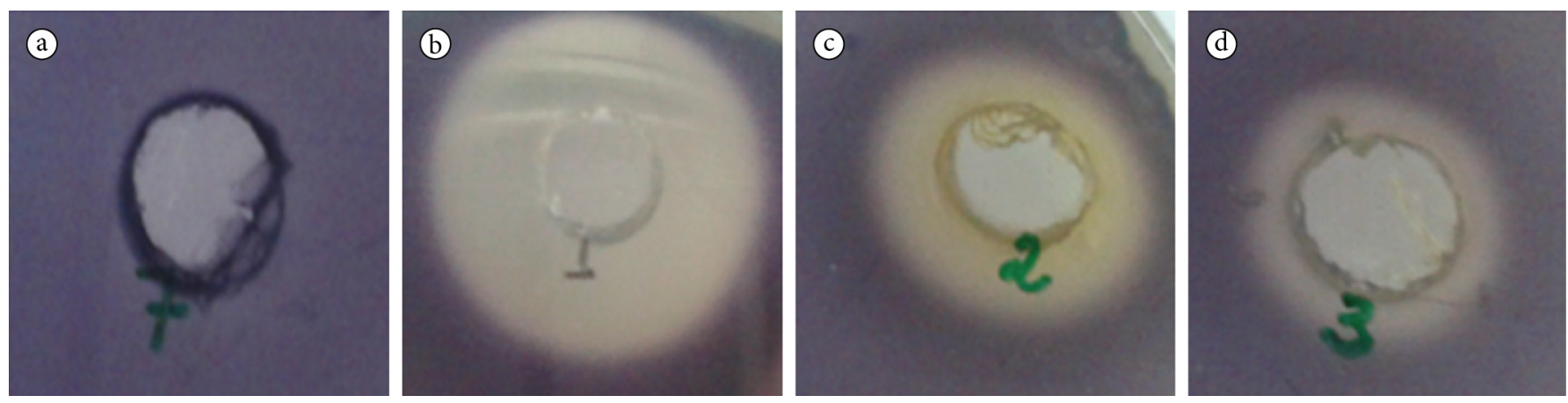

Figure 1. Agar diffusion assay with C. violaceum. (a) Negative control - sterile distilled water, (b) kanamycin $\left(100 \mu \mathrm{g} \mathrm{ml}^{-1}\right)-\mathrm{Control}_{\mathrm{for}}$ bacterial growth inhibition, (c) phenolic extract at $2998.5 \mathrm{mg} \mathrm{GAE} \mathrm{L}^{-1}$ and (d) at $599.70 \mathrm{mg} \mathrm{GAE} \mathrm{L}^{-1}$. 


\subsection{Swarming motility assay}

The phenolic extract from E. brasiliensis had a considerable inhibitory effect against swarming motility of $S$. marcescens while presenting a marginal effect against $A$. hydrophila (Figure 3 ).

\section{Discussion}

The phenolic extract from E. brasiliensis presented a potential for inhibiting quorum sensing in C. violaceum (Figure 1). In the plate diffusion assay, the inhibition in this bacterium can be seen as a lack of purple pigmentation around the well, with no detectable alteration on the bacterial growth, as previously observed (Adonizio et al., 2008; Alvarez et al., 2014). However, this assay can only be considered as a preliminary result, since growth inhibition effects exemplified by the colorless transparent halo formed with kanamycin (Figure 1b) are difficult to be discerned from quorum sensing inhibition which form a turbid colorless halo (Figure 1c and 1c).

Therefore, the extract was further tested in a quantitative and confirmatory assay where it was able to inhibit violacein

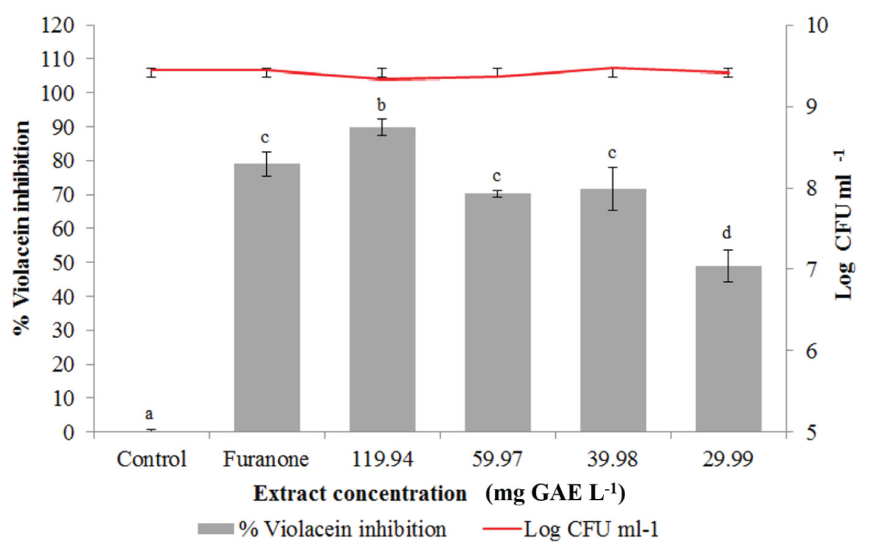

Figure 2. Inhibition of violacein production by different sub-MIC concentrations of phenolic extracts from E. brasiliensis and evaluation of microbial growth ( $\log \mathrm{CFU} \mathrm{m}{ }^{-1}$ ) after $24 \mathrm{~h}$ incubation at $30{ }^{\circ} \mathrm{C}$. The controls consisted of LB broth added of $200 \mu$ of sterile distilled water (no inhibition control) and $39.4 \mu \mathrm{M}$ of furanone (quorum sensing inhibition control). Means followed by the same letter do not differ statistically $(\mathrm{p}<0.05)$. production up to $90 \%$, as compared with the control (Figure 2). A similar effect was observed by Vattem et al. (2007) where violacein production was inhibited from 20 to $60 \%$ by aqueous extracts obtained from raspberry, wild blueberry and grape. The inhibition found in our study was considerably higher than that found by Vattem et al. (2007) probably because we have used extracts enriched for phenolic compounds due to our extraction method, which may contain more effective purified phenolic compounds as opposed to aqueous extracts from those authors. In fact, an extract from fruits of Rubus roaefolius, prepared in similar conditions to the present study, inhibited violacein production with values that approach those observed in this work (Oliveira et al., 2016).

Some studies have shown anti quorum sensing activity of phenolic compounds. For instance, an extract from Kigelia Africana fruits, from the family Bignoniaceae, known for its therapeutic activity due to the presence of phenolic compounds, presented a great potential at inhibiting the production of violacein (Chenia, 2013). Borges et al. (2014) evaluated the quorum quenching activity of isolated phenolic compounds in the concentration of $1000 \mu \mathrm{g} \mathrm{mL}-1$ and found that gallic acid reduced violacein production up to $59 \%$, ferulic acid to $72 \%$, caffeic acid to $75 \%$, phloridzin to $48 \%$, epicatechin to $33 \%$ and oleuropein glucoside to $51 \%$. Another study by Huber et al. (2003) showed anti quorum sensing effects of isolated phenolic compounds such as epigallocatechin gallate (EGCG), gallic acid and tannic acid on the bioluminescence of the quorum sensing biosensor E. coli MT102 pSB403 and the fluorescence of Pseudomonas putida pKR-C12, as well as biofilm formation and swarming motility in Burkholderia cepacia. In another study, the production of violacein was completely abolished by leaves of Centella asiatica $L$. and Adenanthera pavonina $\mathrm{L}$, and the role of flavonoids on this action was suggested (Vasavi et al., 2013).

The composition of phenolic compounds from in E. brasiliensis fruits have been previously characterized as anthocyanins, cyanidin, quercetins, sinapic acids, gallic acid, catechin, epicatechin, flavonoids, ellagic acid, myricetin and rutin (Silva et al., 2014). We hyphotesize that the anti-quorum sensing activity observed in this work is related to the presence of these phenolic compounds acting together against the phenotypes that have been evaluated. Further studies are needed in order to show if the observed effects
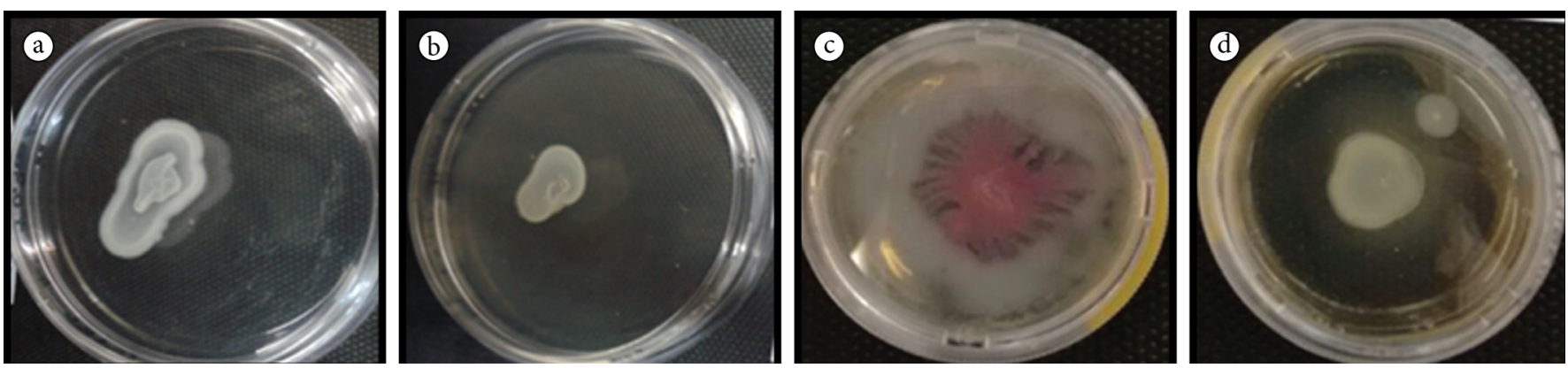

Figure 3. Effect of E. brasiliensis phenolic extract against swarming motility of A. hydrophila and S. marcescens. (a) and (b) tests with A. hydrophila IOC/FDA110-36; (c) and (d) tests with S. marcescens. (a) Control: A. hydrophila IOC/FDA110-36; (b) phenolic extract at 119.94 mg GAE L-1; (c) Control: S. marcescens; (d) phenolic extract at $119.94 \mathrm{mg} \mathrm{GAE} \mathrm{L}^{-1}$. The experiment was performed twice. 
are related to the synergistic effect of the phenolic compounds or to the action of individual components.

In addition to the above mentioned studies, medicinal plants have also been searched for quorum sensing inhibition against violacein production for extracts of Syzygiumcumini L. and Pimenta dioica L (Vasavi et al., 2013) and bioluminescence inhibition in $V$. harveyi for extracts from Rhizophora annamalayanacasca (Musthafa et al., 2013). Seeds from Cuminum cyminum, popularly known as cumin, presented as potent inhibitors of quorum sensing in C. violaceum, with inhibition reaching $86 \%$ with no measurable interference on bacterial growth (Packiavathy et al., 2011). Similar results have been observed for caffeine, with mechanism of action probably related to the inhibition of AHL production (Norizan et al., 2013).

Besides the anti-quorum sensing activity verified by vegetable products, honey and propolis have also been shown to act as inhibitors. As pointed out in the present study, the presence of phenolic compounds in propolis has been attributed as the cause of inhibition (Truchado et al., 2009).

The phenolic extract from $E$. brasiliensis also showed inhibition against swarming motility in A. hydrophila and S. marcescens (Figure 3). Castillo et al. (2015) have shown that epigallocatechin gallate (EGCG), a compound extracted from green tea, inhibited motility in Campylobacter jejuni. Packiavathy et al. (2011) found that Cuminum cyminum extracts inhibited motility in Proteus mirabilis, P. aeruginosa PAO1 and S. marcescens. Alterations in cellular motility could have profound implications for the microorganism's pathogenicity as some virulence genes are normally co-regulated with motility, according to Mccarter (2006).

Teplitski et al. (2000) suggested that plants could produce substances that mimic AHL molecules, interfering with its synthesis or transport and also interacting directly with the receptor LuxR type proteins. Other studies corroborate this assertion (Nazzaro et al., 2013; Tan et al., 2012).

More studies need to be conducted in order to purify and identify the compounds present in the phenolic extract of E. brasiliensis that actually present quorum sensing inhibition activity, as well as to elucidate their mode of action on modeled studied bacteria. The results presented here have important implications since quorum sensing is a global phenomenon employed by bacteria in order to control distinct phenotypes.

\section{Conclusion}

This work presents important findings since there is a scarcity of data showing anti-quorum sensing activity from fruits, especially from native Brazilian species. There is also an increase in the alternative potentials of natural products towards controlling microbial activities. This study showed that phenolic extract from E. brasiliensis presented anti-quorum sensing activity which could have important implications for the food and pharmaceutical industries, inhibiting spoilage and virulence traits that are commonly regulated by quorum sensing in foodborne bacteria.

\section{Acknowledgements}

UMP acknowledges a grant support for this project from CNPq-Brazil (process 486240/2013-4). ACR would like to thank CAPES-Brazil for providing scholarship. ERS and NTBS acknowledge scholarships from Universidade Federal de Ouro Preto from the PIP's program.

\section{References}

Adonizio, A., Kong, K., \& Mathee, K. (2008). Inhibition of quorum sensing-controlled virulence factor production in pseudomonas aeruginosa by south Florida plant extracts. Antimicrobial Agents and Chemotherapy, 52(1), 198-203. http://dx.doi.org/10.1128/ AAC.00612-07. PMid:17938186.

Alvarez, M. V., Ortega-Ramirez, L. A., Gutierrez-Pacheco, M. M., Bernal-Mercado, T., Rodriguez-Garcia, I., Gonzalez-Aguilar, G. A., Ponce, A., Moreira, M. R., Roura, S. I., \& Ayala-Zavala, F. F. (2014). Oregano essential oil-pectin edible films as anti-quorum sensing and food antimicrobial agents. Frontiers in Microbiology, 5, 1-7. http://dx.doi.org/10.3389/fmicb.2014.00699. PMid:25566215.

Bai, A., \& Rai, V. (2011). Bacterial quorum sensing and food industry. Comprehensive Reviews in Food Science and Food Safety, 10(3), 184194. http://dx.doi.org/10.1111/j.1541-4337.2011.00150.x.

Bertoldi, M. C. (2009). Antioxidant capacity, anticancer effects and absorption of mango (Mangifera indica L.) polyphenos in vitro (Tese de doutorado). Universidade Federal de Viçosa, Viçosa.

Borges, A., Serra, S., Abreu, A. C., Saavedra, M. J., Salgado, A., \& Simões, M. (2014). Evaluation of the effects of selected phytochemicals on quorum sensing inhibition and in vitro cytotoxicity. Biofouling, 30(2), 183-195. http://dx.doi.org/10.1080/08927014.2013.852542. PMid:24344870.

Castillo, S., Heredia, N., \& García, S. (2015). 2 (5H)-Furanone, epigallocatechin gallate, and a citric-based disinfectant disturb quorum-sensing activity and reduce motility and biofilm formation of Campylobacter jejuni. Folia Microbiologica, 60(1), 89-95. http:// dx.doi.org/10.1007/s12223-014-0344-0. PMid:25231135.

Chenia, H. Y. (2013). Anti-quorum sensing potential of crude kigelia africana fruit extracts. Sensors (Basel, Switzerland), 13(3), 2802-2817. http://dx.doi.org/10.3390/s130302802. PMid:23447012.

Dong, Y. H., Wang, L. H., Xu, J. L., Zhang, H. B., Zhang, X. F., \& Zhang, L. H. (2001). Quenching quorum-sensing dependent bacterial infection by an $\mathrm{N}$-acyl homoserine lactonase. Nature, 411(6839), 813-817. http://dx.doi.org/10.1038/35081101. PMid:11459062.

Fuqua, W. C., Winans, C. W., \& Greenberg, E. P. (1994). Quorum sensing in bacteria: the LuxR-LuxI family of cell density-responsive transcriptional regulators. Journal of Bacteriology, 176(2), 269-275. PMid:8288518.

Givskov, M. (2012). Beyond nutrition: health-promoting foods by quorum sensing inhibition. Future Microbiology, 7(9), 1025-1028. http://dx.doi.org/10.2217/fmb.12.84. PMid:22953702.

González, J. E., \& Keshava, N. D. (2006). Messing with bacterial quorum sensing. Microbiology and Molecular Biology Reviews, 70(4), 859875. http://dx.doi.org/10.1128/MMBR.00002-06. PMid:17158701.

Haminiuk, C. W., Maciel, G. M., Plata-Oviedo, M. S., \& Peralta, R. M. (2012). Phenolic compounds in fruits-an overview. International Journal of Food Science \& Technology, 47(10), 2023-2044. http:// dx.doi.org/10.1111/j.1365-2621.2012.03067.x.

Hentzer, M., \& Givskov, M. (2003). Pharmacological inhibition of quorum sensing for the treatment of chronic bacterial infections. 
The Journal of Clinical Investigation, 112(9), 1300-1307. http://dx.doi. org/10.1172/JCI20074. PMid:14597754.

Hentzer, M., Wu, H., Andersen, J. B., Riedel, K., Rasmussen, T. B., Bagge, N., Kumar, N., Schembri, M. A., Song, Z., Kristoffersen, P., Manefield, M., Costerton, J. W., Molin, S., Eberl, L., Steinberg, P., Kjelleberg, S., Høiby, N., \& Givskov, M. (2003). Attenuation of Pseudomonas aeruginosa virulence by quorum sensing inhibitors. The EMBO Journal, 22(7), 3803-3815. http://dx.doi.org/10.1093/ emboj/cdg366. PMid:12881415.

Huber, B., Eberl, L., Feucht, W., \& Polster, J. (2003). Influence of polyphenols on bacterial biofilm formation and quorum-sensing. Zeitschrift für Naturforschung, 58(11), 879-884. PMid:14713169.

Huber, B., Riedel, K., Hentzer, M., Heydorn, A., Gotschlich, A., Givskov, M., Molin, S., \& Eberl, L. (2001). The cep quorum-sensing system of Burkholderia cepacia H111 controls biofilm formation and swarming motility. Microbiology, 147(9), 2517-2528. http://dx.doi. org/10.1099/00221287-147-9-2517. PMid:11535791.

Issac Abraham, S. V., Palani, A., Ramaswamy, B. R., Shunmugiah, K. P., \& Arumugam, V. R. (2011). Anti-quorum sensing and antibiofilm potential of Capparis spinosa. Archives of Medical Research, 42(8), 658668. http://dx.doi.org/10.1016/j.arcmed.2011.12.002. PMid:22222491.

Magina, M. D. A., Dalmarco, E. M., Wisniewski, J. R., Simionatto, E. L., Dalmarco, J. B., Pizzolatti, M. G., \& Brighent, I. M. C. (2009). Chemical composition and antibacterial activity of essential oils of Eugenia species. Journal of Natural Medicines, 63(3), 345-350. http:// dx.doi.org/10.1007/s11418-009-0329-5. PMid:19308653.

Manefield, M., Nys, R., Kumar, N., Read, R., Givskov, M., Steinberg, P., \& Kjelleberg, S. (1999). Evidence that halogenated furanones from Delisea pulchra inhibit acylated homoserine lactone (AHL)mediated gene expression by displacing the AHL signal from its receptor protein. Microbiology, 145(2), 283-291. http://dx.doi. org/10.1099/13500872-145-2-283. PMid:10075410.

Martins, M. L., Pinto, U. M., Riedel, K., Vanetti, M. C. D., Mantovani, H. C., \& Araújo, E. F. (2014). Lack of AHL-based quorum sensing in Pseudomonas fluorescens isolated from milk. Brazilian Journal of Microbiology, 45(3), 1039-1046. http://dx.doi.org/10.1590/S151783822014000300037. PMid:25477941.

Martins, N., Barros, L., Henriques, M., Silva, S., \& Ferreira, I. C. (2015). Activity of phenolic compounds from plant origin against Candida species. Industrial Crops and Products, 74, 648-670. http://dx.doi. org/10.1016/j.indcrop.2015.05.067.

Mccarter, L. L. (2006). Regulation of flagella. Current Opinion in Microbiology, 9(2), 180-186. http://dx.doi.org/10.1016/j.mib.2006.02.001. PMid:16487743.

Moreno, P. R. H., Lima, M. E. L., Sabral, M., Young, M. C. M., Cordeiro, I., Apel, M. A., Linberger, R. P., \& Henriques, A. T. (2007). Essential oil composition of fruit colour varieties of Eugenia brasiliensis lam. Scientia Agricola, 64(4), 428-432. http://dx.doi.org/10.1590/S010390162007000400014.

Morohoshi, T., Shiono, T., Takidouchi, K., Kato, M., Kato, N., Kato, J., \& Ikeda, T. (2007). Inhibition of Quorum Sensing in Serratia marcescens AS-1 by Synthetic Analogs of $N$-Acylhomoserine Lactone. Applied and Environmental Microbiology, 73(20), 6339-6344. http://dx.doi. org/10.1128/AEM.00593-07. PMid:17675425.

Musthafa, K. S., Sahu, S. K., Ravi, A. V., \& Kathiresan, K. (2013). Antiquorum sensing potential of the mangrove Rhizophora annamalayana. World Journal of Microbiology \& Biotechnology, 29(10), 1851-1858. http://dx.doi.org/10.1007/s11274-013-1347-8. PMid:23591758.

Nazzaro, F., Fratianni, F., \& Coppola, R. (2013). Quorum sensing and phytochemicals. International Journal of Molecular Sciences,
14(6), 12607-12619. http://dx.doi.org/10.3390/ijms140612607. PMid:23774835.

Norizan, S. N. M., Yin, W., \& Chan, K. (2013). Caffeine as a Potential Quorum Sensing Inhibitor. Sensors (Basel, Switzerland), 13(4), 5117-5129. http://dx.doi.org/10.3390/s130405117. PMid:23598500.

Oliveira, B., Rodrigues, A. C., Cardoso, B. M. I., Ramos, A. L. C. C., Bertoldi, M. C., Taylor, J. G., Cunha, L. R., \& Pinto, U. M. (2016). Antioxidant, antimicrobial and anti-quorum sensing activities of Rubus rosaefolius phenolic extract. Industrial Crops and Products, 84, 59-66. http://dx.doi.org/10.1016/j.indcrop.2016.01.037.

Packiavathy, I. A. S. V., Agilandeswari, P., Musthafa, K. S., Pandian, S. K., \& Ravi, A. V. (2011). Antibiofilm and quorum sensing inhibitory potential of Cuminum cyminum and its secondary metabolite methyl eugenol against Gram negative bacterial pathogens. Food Research International, 45(1), 85-92. http://dx.doi.org/10.1016/j. foodres.2011.10.022.

Pinto, U. M., Viana, E. S., Martins, M. L., \& Vanetti, M. C. D. (2007). Detection of acylated homoserine lactones in gram-negative proteolytic psychrotrophic bacteria isolated from cooled raw milk. Food Control, 18(10), 1322-1327. http://dx.doi.org/10.1016/j.foodcont.2006.09.005.

Ponce-Rossi, A. R., Pinto, U. M., Ribon, A. O. B., Bazzolli, D. M. S., \& Vanetti, M. C. D. (2016). Quorum sensing regulated phenotypes in Aeromonas hydrophila ATCC 7966 deficient in AHL production. Annals of Microbiology, (in press)

Rasko, D. A., \& Sperandio, V. (2010). Anti-virulence strategies to combat bacteria-mediated disease. Nature Reviews. Drug Discovery, 9(2), 117-128. http://dx.doi.org/10.1038/nrd3013. PMid:20081869.

Ravn, L., Christensen, A. B., Molin, S., Givskov, M., \& Gram, L. (2001). Methods for detecting acylated homoserine lactones produced by Gram-negative bacteria and their application in studies of AHLproduction kinetics. Journal of Microbiological Methods, 44(3), 239-251. http://dx.doi.org/10.1016/S0167-7012(01)00217-2. PMid:11240047.

Shahidi, F. Z., \& Naczk, M. (1996). Food phenolics: sources, chemistry, effects and applications. Food Chemistry, 3(8), 418-482.

Silva, N. A., Rodrigues, E., Mercadante, A. Z., \& Rosso, V. V. (2014). Phenolic compounds and carotenoids from four fruits native from the Brazilian atlantic forest. Journal of Agricultural and Food Chemistry, 6(22), 5072-5084. http://dx.doi.org/10.1021/jf501211p. PMid:24780053.

Skandamis, P. N., \& Nychas, G. J. (2012). Quorum sensing in the context of food microbiology. Applied and Environmental Microbiology, 78(16), 5473-5482. http://dx.doi.org/10.1128/AEM.00468-12. PMid:22706047.

Tan, L. Y., Yin, W. F., \& Chan, K. G. (2012). Silencing quorum sensing through extracts of melicope lunu-ankenda. Sensors (Basel, Switzerland), 12(4), 4339-4351. http://dx.doi.org/10.3390/s120404339. PMid:22666033.

Teplitski, M., Robinson, J. B., \& Bauer, W. D. (2000). Plants secrete substances that mimic bacterial n-acyl homoserine lactone signal activities and affect population density-dependent behaviorsin associated bacteria. Molecular Plant-Microbe Interactions, 13(6), 637648. http://dx.doi.org/10.1094/MPMI.2000.13.6.637. PMid:10830263.

Tiveron, A. P., Melo, P. S., Bergamaschi, K. B., Vieira, T. M., Regitanod'Arce, M. A., \& Alencar, S. M. (2012). Antioxidant activity of Brazilian vegetables and its relation with phenolic composition. International Journal of Molecular Sciences, 13(7), 8943-8957. http:// dx.doi.org/10.3390/ijms13078943. PMid:22942744.

Truchado, P., López-Gálvez, F., Gil, M. L., Tomás-Baberàn, F. A., \& Allende, A. (2009). Quorum sensing inhibitory and antimicrobial activities of honeys and the relationship with individual phenolics. 
Food Chemistry, 115(4), 1337-1344. http://dx.doi.org/10.1016/j. foodchem.2009.01.065.

Tsai, C. S., \& Winans, S. C. (2010). LuxR-type quorum-sensing regulators that are detached from common scents. Molecular Microbiology, 77(5), 1072-1082. http://dx.doi.org/10.1111/j.1365-2958.2010.07279.x. PMid:20624221.

Vasavi, H. S., Arun, A. B., \& Rekha, P. D. (2013). Inhibition of quorum sensing in Chromobacterium violaceum by Syzygium cumini L. and Pimenta dioica L. Asian Pacific Journal of Tropical Biomedicine,
3(12), 954-959. http://dx.doi.org/10.1016/S2221-1691(13)60185-9. PMid:24093786.

Vattem, D. A., Mihalik, K., Crixell, S. H., \& Mcleand, R. J. (2007). Dietary phytochemicals as quorum sensing inhibitors. Fitoterapia, 78(4), 302310. http://dx.doi.org/10.1016/j.fitote.2007.03.009. PMid:17499938.

Wiegand, I., Hilpert, K., \& Hancock, R. E. W. (2008). Agar and broth dilution methods to determine the minimal inhibitory concentration (MIC) of antimicrobial substance. Nature Protocols, 3(2), 163-175. http://dx.doi.org/10.1038/nprot.2007.521. PMid:18274517. 